\title{
BOCÁNGEL'S SILVA «EL RETRATO»: A TEXTUAL TROJAN HORSE?
}

\author{
LA SILVA «EL RETRATO», DE BOCÁNGEL: ¿UN CABALLO DE TROYA?
}

Leticia Mercado

Colby College

\begin{abstract}
Gabriel Bocángel's silva «El retrato» (c. 1638) is a textual Trojan horse in the war for poetic patronage in the early modern Spanish court. Written on the wedding of the poet's cousin to Juan de Cetina, secretary to the Admiral of Castile, the poem is a verbal portrait of the bride that undermines not only the tradition of the descriptio puellae, but also the Count-Duke of Olivares's power. As a panegyric of the latter's enemy, the text employs the botanical images of the laurel and the ivy, exploiting the full sense of their symbolic meaning. As an appeal for the patronage of poetry and letters at court and an exercise in «self-fashioning» (Greenblatt), the text makes the lovers' and the poet's pursuits parallel to the "siege» of Daphne; the poet, as a new Apollo, sings and weaves a complex poetic fabric in which different tensions are ultimately resolved in the image of the Admiral's laurelcrowned brow, to which both the couple's and the poet's ambitions aspire.
\end{abstract}

KEYWORDS: Bocángel; Patronage; Silva; Olivares; Baroque; Emblems.

RESUMEN • La silva «El retrato» (c. 1638) de Gabriel Bocángel es un caballo de Troya en la guerra por el patronazgo poético en el contexto de la corte española del siglo XVII. Escrita con motivo de la boda de la prima del poeta con Juan de Cetina, secretario del Almirante de Castilla, el poema es un retrato verbal de la novia que socava no sólo la tradición de la descriptio puellae, sino el poder del Conde-Duque de Olivares, enemigo acérrimo del Almirante. Como panegírico de este último, el texto emplea las imágenes botánicas del laurel y la hiedra explotando el pleno sentido de su significado emblemático y simbólico. Como petición de patronazgo de la poesía y las letras en la corte y como ejercicio de «self-fashioning» (Greenblatt), el texto pone en paralelo los objetivos de los amantes y del poeta con el acoso a Dafne; como nuevo Apolo, el poeta canta tejiendo un complejo tapiz en el que distintas tensiones se resuelven finalmente en la imagen de la frente del Almirante, coronada de laureles, a la que aspiran por igual las ambiciones de los amantes y del propio poeta.

PALABRAS CLAVES: Bocángel; Patronazgo; Silva; Olivares; Barroco; Emblemas. 
Around 1638-39, Spanish poet Gabriel Bocángel (1603-1658) composed a celebratory «silva nupcial» on the occasion of the wedding of his cousin, doña Jerónima de Maldonado, to Juan de Cetina, secretary to Juan Alfonso Enríquez de Cabrera y Colonna (1599-1647), $9^{\text {th }}$ Admiral of Castile. ${ }^{1}$ Trevor Dadson has argued that the silva asserts the poet's allegiance to such a powerful patron on its title page, in which Bocángel dedicates the poem to the «Excelentíssimo señor Almirante de Castilla, General de los exércitos de su Magestad en España, \&c. Gran Defensor de su Religión, y de su Monarchía" (1983: 43-44). Dadson conceives the text's objective as the poet's petition for favor, as well as his subtle declaration of support against the most declared enemy of the Admiral's, Gaspar de Guzmán y Pimentel (1587-1645), Count-Duke of Olivares, valido to King Philip IV of Spain. Dadson bases his argument on the fact that Olivares had gained unmerited praise and recognition for the defeat of Richelieu's army at the siege of the Spanish city of Fuenterrabía (1638), during the Franco-Spanish War (1635-59), in which Cabrera y Colonna, and not Olivares, had led the Spanish army into victory (2000: 636, n. to verse 1$).^{2}$

This study proposes a re-examination of the silva as a defense of the role of poetry at court and a commentary on the nature of the true leader. The poem builds this defense on two main rhetorical strategies: on the one hand, the depiction of the Admiral as a military uictor, fashioned after the great leaders of ancient Rome. On the other hand, the recourse to the symbolic meanings of three plants, the laurel, the olive, and the ivy, which the early modern tradition draws majorly from classical sources. In the combination of these two strategies, the silva fashions the perfect leader as not only capable of bringing victory and peace to the nation, but most importantly as willing to set aside "las armas» (weapons or arms) in favor of «las letras» (learning, letters) at times of peace, and letting his laurel-adorned brow be crowned by the ivy crown of the patron (Trapp, 1958: 229). The text crosses the boundaries of laudatory poetry into the territory of moral instruction in the tradition of the principum speculum, commenting on the role of poetry in relation to power and the ability of poetic language to fashion both self and other.

The poem opens "with a lengthy panegyric on the Admiral [...] followed by a direct reference to the recent victory over the French at Fuenterrabía" (Dadson, 1979: 37-38), to elaborate a verbal portrait of Jerónima framed in the poetical tradition of the descriptio puellx and ekphrasis. ${ }^{3}$ Even when the task is referred to in verses 30-126, the description of the lady does not being until verse 52; the previous verses anchor the reader's attention to the image of the Admiral, fashioned as a triumphant Roman general after a conquest: a man burdened and exhausted by his duties enjoying in a rare moment of leisure. The Admiral's

1. In this article, I cite from Trevor Dadson's edition of Bocángel's complete poems (2000). Dadson notes that the silva contains no reference to its original date of printing, and suggests 1638-39 as an approximate date for doña Jerónima's wedding to Cetina (2000: 635, n. 1).

2. For these data, see Dadson 1979 and 1983: 43-44. The Franco-Spanish war was parallel to the European Thirty Year's War (1618-48). On Bocángel's life and works, see Alda Tesán, Benítez Claros, Blanco, Cano, Cossío, numerous studies by Dadson, which would be difficult to cite here, Fontana Elboj, González, Mercado, Molho, Morros Mestres, Orozco Díaz, Peralta, and Torres 1998, 2000, and 2006. On Olivares and the poets of his time, see Carreira. On Olivares's self-created public image, see Mínguez Cornelles and Rodríguez Moya, who note the presence of olive leaves or crowns in some of the Count-Duke's iconographical representations (see 409-410). As to Bocángel, Dadson 1983b includes a bibliography on works by and on the poet. On Spain and the Thirty Years War, see Brightwell, Cooper, Elliott, Lesaffer 2006a and 2006b, Parker, Wilson, and Palafox y Mendoza, a book commissioned by King Philip IV. The triumph of the Spanish army is still commemorated in Fuenterrabía (Hondarribia) in a parade called «El alarde de Hondarribia».

3. See Dadson, 1979: 37. The silva has received little critical attention, as far as I have been able to ascertain. 
brow is metaphorically, and perhaps literally, covered by «de Belona [Roman goddess of war] los sudores» (6), that is, by perspiration due to effort in his recent military campaigns.

Like rapid brushstrokes, several poetic images in the first stanza are visual echoes of the appearance of the conqueror in the ceremony of the Roman triumphus, "the most outstanding honor a Roman general could hope for" (Beard, 2007: 1). The uictor who had been awarded a triumph would parade through the city in a four-horse chariot decorated with laurel branches, crowned with laurel, and with his face painted red (Versnel, 1970: 57)according to Pliny, sometimes his whole body would be painted red (cited in Beard, 2007: 84). ${ }^{4}$ Verses 13 to 15 echo this image by presenting the Admiral bathed in the blood of his enemies: "Agora sólo atiendas / a designar a España nuevas glorias / en sangre noble del francés teñido». The poetic voice's palette of reds and purples echo the purple toga palmata and toga picta which Roman generals would wear in a triumph. Whether these connections respond to Bocángel's knowledge of classical sources or not, the depiction of the Admiral as a uictor that they construct responds to the need for a patron that characterizes the situation of most poets in seventeenth-century Spain (Blanco, 1988: 203). ${ }^{5}$

Two botanical images are the foundations of the portrayal of the Admiral as the perfect soldier. The first one is the laurel or bay tree (dafné, in Greek), which traditionally considered a tree sacred to god Apollo and related to prophecy -as the pythia interpreted the god's messages at the god's oracle using laurel to induce visions-, as well to protection against peril or the spirits of the underworld (Heckscher, 1992: 209). However, it was above all the mark of the uictor, "a concept first introduced by Apollo, after he had slain the Python" (Heckscher, 1992: 210). The crown of laurel appears in numerous early modern of works of literature and visual art symbolizing its first and most familiar meaning, the idea of military triumph. Cesare Ripa crowns virtue with laurel in the Siena 1613 edition of Iconologia (originally published in Rome, 1593): "Giovanetta alata, $\theta$ modestamente vestita, sarà coronata di lauro, $\theta$ in mano terrà un ramo di quercia, con un motto nel lembo della veste» (1613: 355, II).

Early modern European books of emblems also depict the laurel wreath in connection to fame and triumph. In the Frankfurt 1661 edition of Symbolorum et Emblematum ex Re Herbaria (first printed in Nuremberg, 1590), Iohannes Camerarius the Younger included an emblem that depicts a crown wreathed in olive and laurel (50, Centuria I), "Si recte facies» (if you do well) [fig. 1]. The motto is a phrase from Horace's Epistulae (first century B.C.): " Rex eris', aiunt, 'si recte facies' [...]" (if you do well, thou shalt be crowned) (1.1.59-60). It refers to constancy and fortitude, symbolized by both plants, as the virtues necessary for princes, who should not only exercise their power to oppress. If the crown of olive and laurel warns about the nature of the perfect leader, then Bocángel's crowning of the Admiral implies an indirect critique to Olivares, which would support the case for the silva as a political gesture. Yet the analysis of its symbolic references reveals that the silva aims at more than a mere attack on the Conde-Duque.

4. See also Versnel, 1970: 56-93. There is no consensus on the triumph among scholars of ancient Roman history. Versnel has argued that during a triumphus, a conqueror could be the representation of Jupiter, or else of the rex, and that the color red imitated the statues of Jupiter, which were possibly red-leaded. Red could also stand for blood, which in primitive times might have been actual blood, or the sun. Beard does not find sufficient evidence to affirm that these were uniform practices throughout the history of Rome (232). On the Roman triumph, see Auliard, Barini, Bastien, Beard, Brilliant, La Rocca and Tortorella, Payne, Sumi, and Popkin.

5. Due to his employment as librarian to Cardinal-Infant don Fernando de Austria (1609-1641) (Dadson, 1983: $34)$, it is possible to assume that the poet may have had access to accounts of Roman triumphs, such as Isidore of Seville's (c. 560-636) Etymologies (c. 1625), book XVIII (ii, 1-6).

IMAGO, NÚM. I I, 2019, I I I-133 


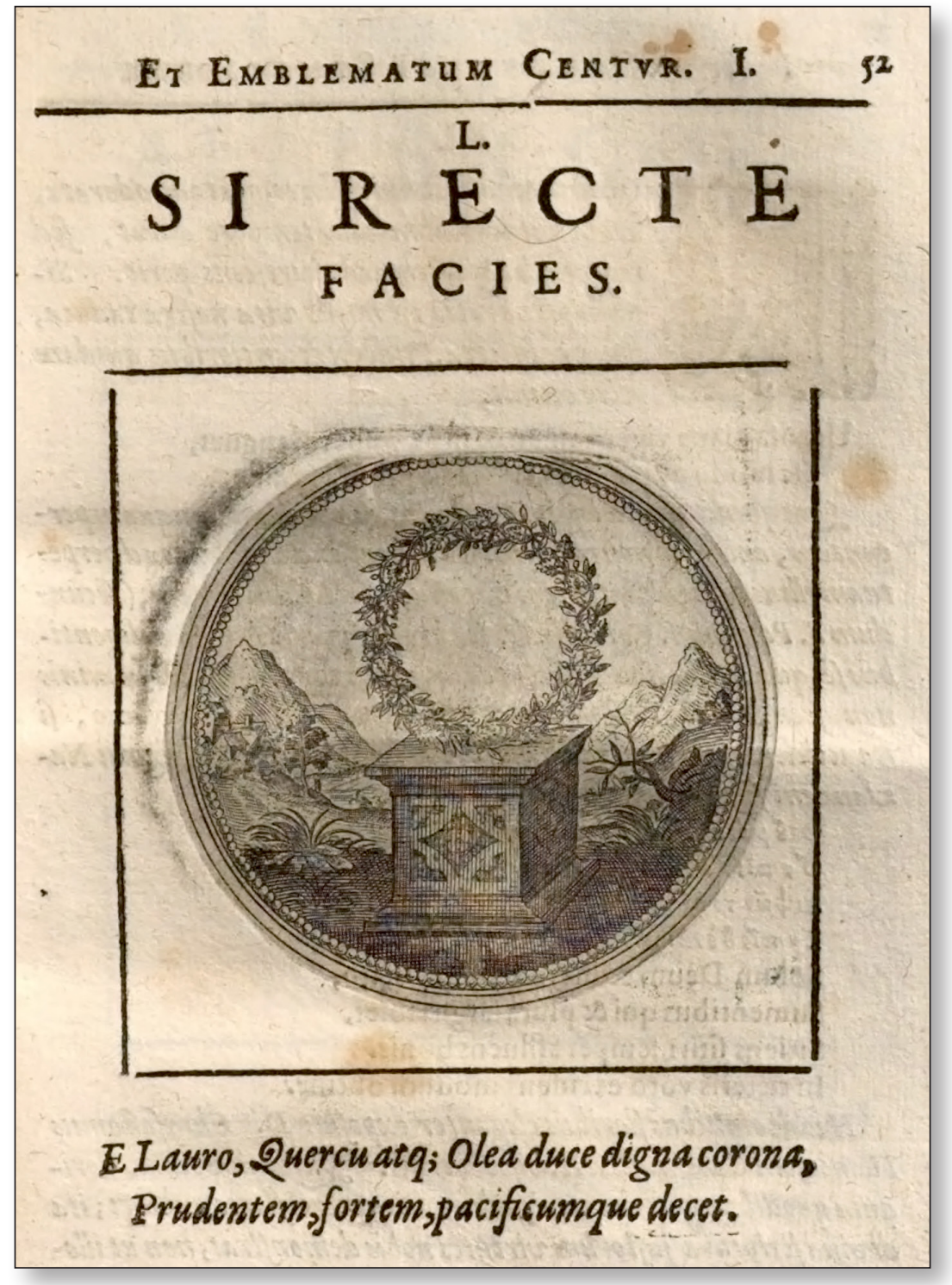

Fig. 1. Iohannes Camerarius the Younger, Symbolorum et Emblematum ex Re Herbaria (Frankfurt, 1661). Cent. I, emb. 50 (Image courtesy of Bayerische Staatsbibliothek München, shelfmark Augsburg, Staats-und Stadtbibliothek - 4 Kst 401, folio 52r , URN urn:nbn:de:bvb:12-bsb11215985-6).

The image of the crown of laurel portrays the Admiral as the paradigm of military virtue because it establishes a parallel of his merits to those of Emperor Charles V, the embodiment of the idea of power, in the golden days of the Spanish Empire at the peak of its military power. Andrea Alciato's (1492-1550) Emblemata (first published in Augsburg as Emblematum liber in 1531) included for the first time in the 1546 Venice edition the depiction of the laurus nobilis in emblem 211, "Laurus». In the Padua 1621 edition, [fig. 2] the pictura represents Apollo's altar and tripod where some laurel twigs are burning alongside with the effigy of emperor Charles V, crowned with laurel as the model leader after his victory over 
Tunisia in 1535; the subscriptio reads "Now that the Poeni [North Africans / Tunisians] have been defeated, Charles deserves the laurel- let wreaths of laurel adorn the victor's locks». ${ }^{6}$ The Lyon 1549 edition, titled Les emblemes, specifies that "Les Empereurs après leurs conquestes, e victoires, triumphans portoient le Laurier en main, $\theta$ en teste, en branche, $\theta$ en coronne». ${ }^{7}$ This emblematic representation seems to draw from Pliny's account of the uses of wreaths.

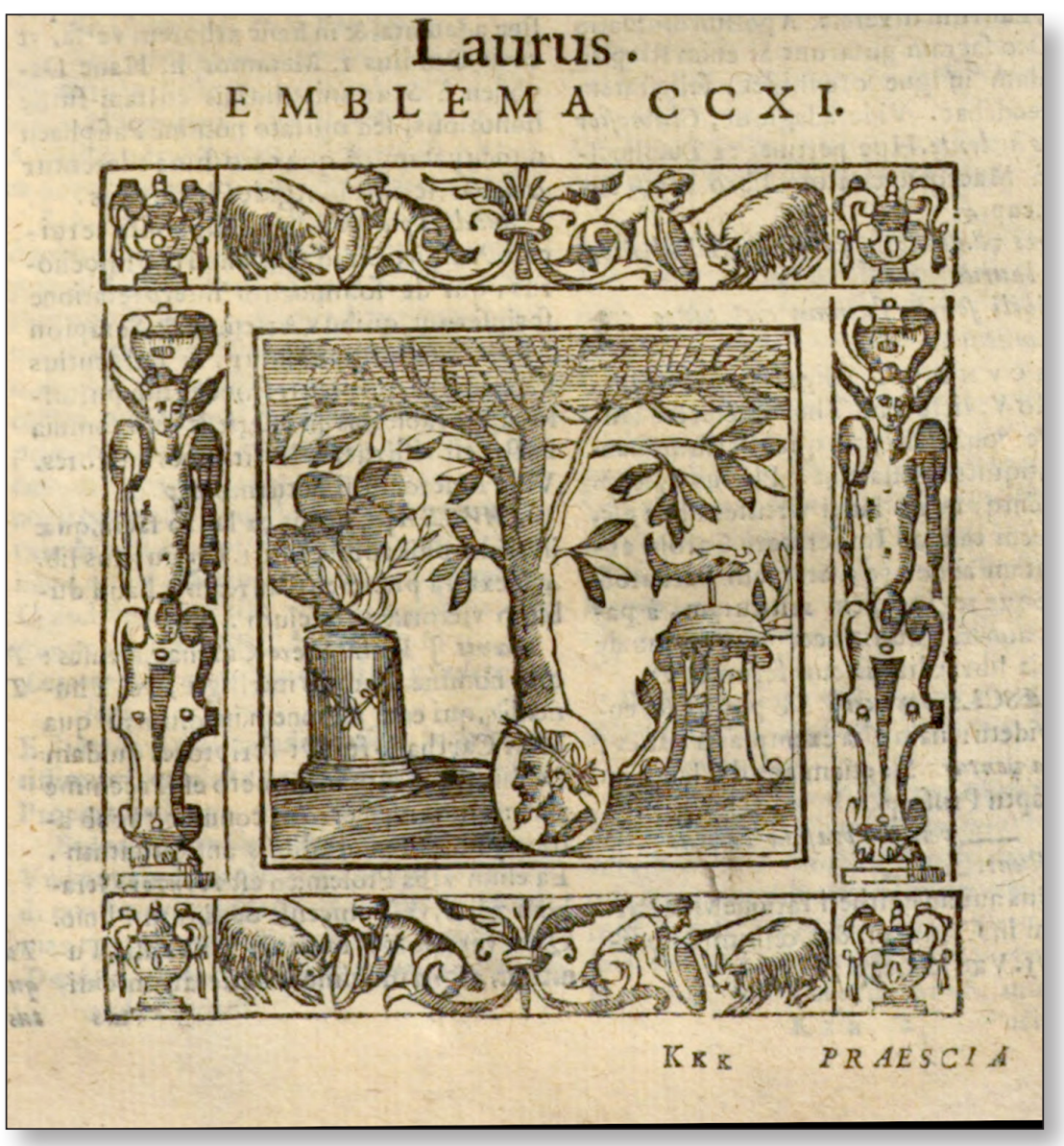

Fig. 2. Andrea Alciato, Emblemata (Padua, 1621). Emb. 211 (Image courtesy of Bayerische Staatsbibliothek München, shelfmark Regensburg, Staatliche Bibliothek - 999/4Lat. rec.40, folio 881v, URN urn:nbn:de:bvb:12-bsb11068683-2).

The laurel crown also symbolizes merit and virtue in Juan de Borja's (1533-1606) Empresas morales (Prague, by Iorge Nigrin, 1581). Emblem 1, "Meruisse satis» (it is sufficient to have deserved it) [fig. 3], depicts in the pictura a laurel crown suspended in air. ${ }^{8}$ The text explains

6. See Heckscher, 1992: 208. The English translation is from Alciato in Glasgow <emblems.arts.gla.ac.uk/alciato/ emblem.php?id=A2 1a21 1 > 2-12-17.

7. <emblems.arts.gla.ac.uk/alciato/facsimile.php?id=sm33_r3r>2-12-17.

8. The English translations of Latin mottoes from Borja, Soto, Mendo, and Saavedra Fajardo are taken from Bernat Vistarini and Cull.

IMAGO, NÚM. I I, 2019, I I I-I33 
that one must work hard to achieve merit, symbolized by the crown, even if one's services are not recognized and praised accordingly in this world, as the practice of virtue merits the prize of eternal life. In emblem 78, "Victi, non victores» (the conquered, and not the conquerors) [fig. 4], depicts a laurel crown. The gloss focuses on the idea those who act according to what their faith dictates will achieve the crown that is reserved in life for conquering armies and victors in competencies. In this context, Bocángel's portrayal of a doubly crowned Admiral can be read as a reference to the latter's unrecognized merit, constancy, and effort, and as a general warning that the perfect leader is a humble and virtuous one.

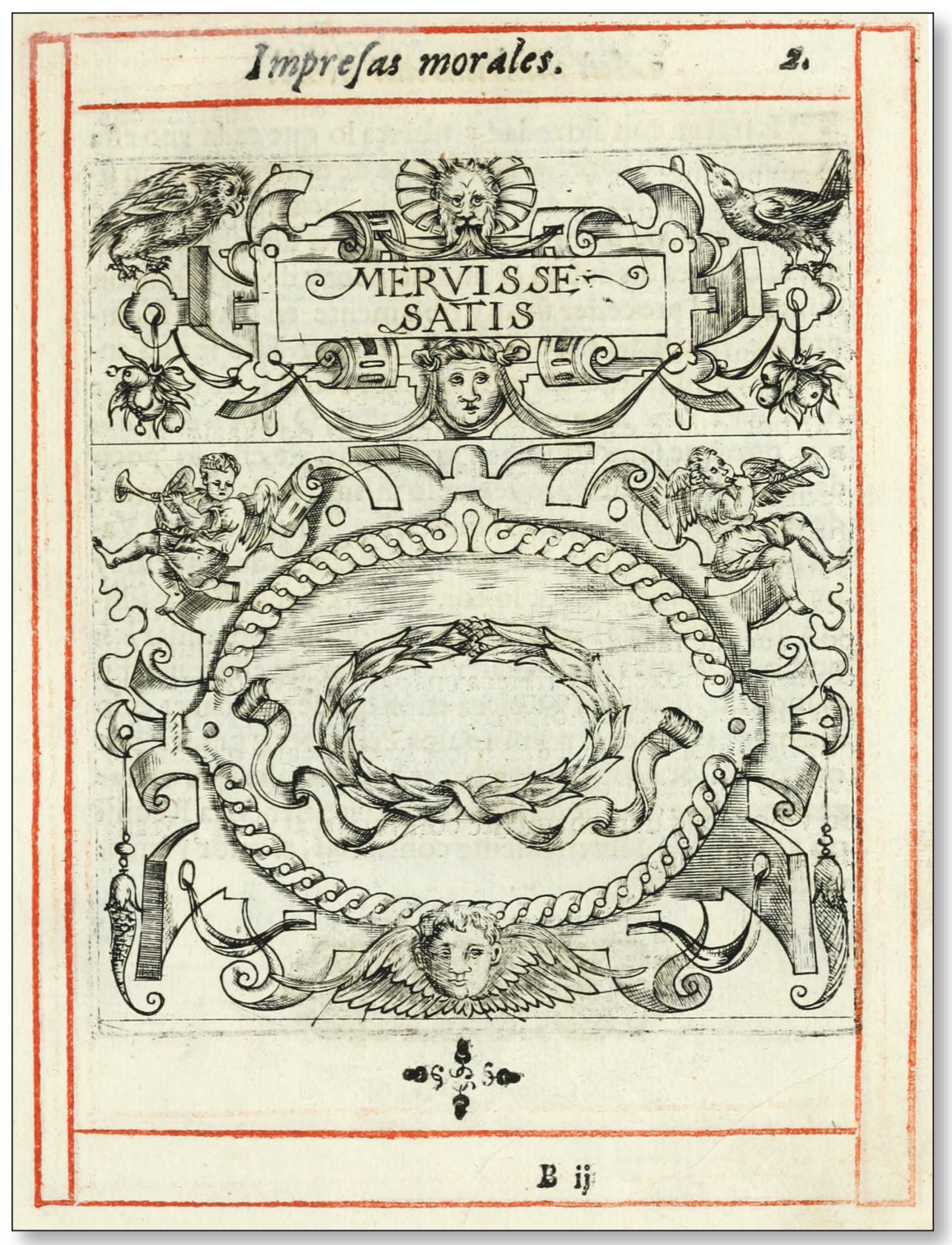

Fig. 3. Juan de Borja, Empresas Morales (Prague, 1581). Emb. 1 (Image courtesy of Emblematica Online, University of Illinois at Urbana-Champaign). 


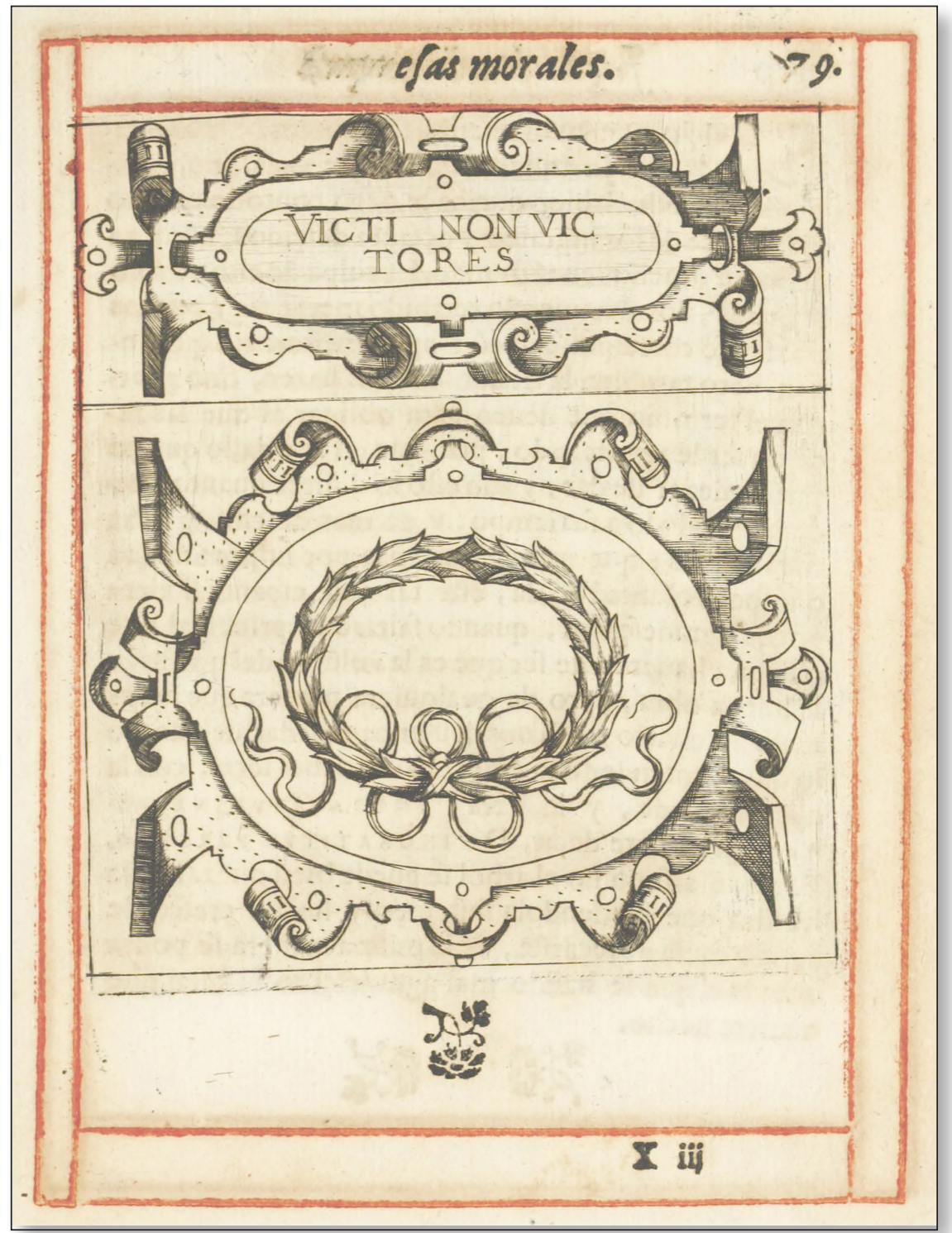

Fig. 4. Juan de Borja, Empresas Morales (Prague, 1581). Emb. 78 (Image courtesy of Emblematica Online, University of Illinois at Urbana-Champaign).

The reference to the union of the crown of olive to the laurel in verse 3 reinforces the fashioning of the Admiral as a model victor. However, like the laurel, the olive tree had connections not only to triumph, but also to the concept of virtue. The olive often appears in depictions of the optimus ciuis or best citizen, who merits the olive wreath in recognition of noble and virtuous actions. In emblem 135, "Optimus ciuis» (the best citizen) [fig. 5] (Emblemata, Padua, 1621), the textual commentaries by Francisco Sánchez de las Brozas (1523-1600) complete the story told in the pictura and the subscriptio, that of the Athenian general Thrasybulus, who defended democracy and liberated Athens from the tyranny of 
the Thirty in the fourth century B.C. The pictura depicts the citizens of Athens in the act of honoring Thrasybulus with the olive wreath. Following the classical model, Bocángel crowns the Admiral with olive to fashion him as optimus ciuis, deserving of the maximum honor for his sacrifice and achievements, for which Olivares had received praise. ${ }^{9}$ The crossroads of word and image serves to convey the connotation that the Admiral is the kind of leader who is capable of opposing and resisting absolute power in favor of the people, as opposed to Olivares's policies.

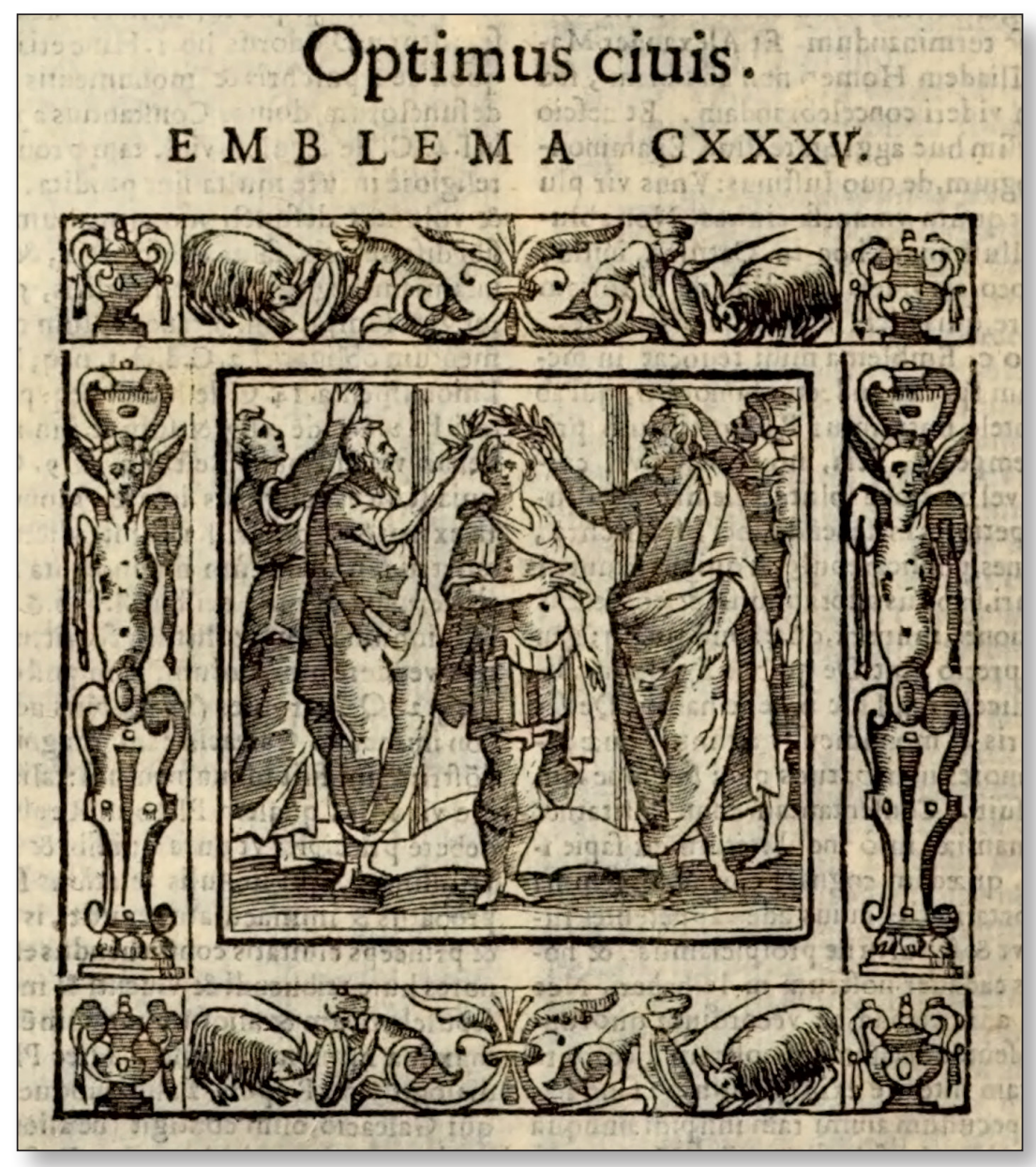

Fig. 5. Andrea Alciato, Emblemata (Padua, 1621). Emb. 135 (Image courtesy of Bayerische Staatsbibliothek München, shelfmark Regensburg, Staatliche Bibliothek - 999/4Lat. rec.40, folio 576rv, URN urn:nbn:de:bvb:12-bsb11068683-2).

As the tree of Pallas Athena or Minerva (Wittkower, 1939: 199), the olive tree also symbolizes peace, in opposition to Mars and Bellona, god and goddess of war and conquest,

9. The 1615 Nájera edition, with commentaries by Diego López, depicts the "optimus ciuis» in emblem 133, which explains that the olive crown was called «Palladiae» because the olive tree was found by goddess Pallas, protectress of Athens (1615: 326-327). Emblem 23 «Vino prudentiam augeri» (wisdom increased by wine), narrates the anecdote.

IMAGO, NÚM. II, 2019, III-133 
who would be related to the laurel. Ripa portrays «Pace» as a woman holding an olive branch and crowned with olive, and referes to "concordia" as a female figure that "Si corona d'olivo, per segno di pace, effetto della Concordia» (1613: 182). In the emblematic tradition, Diego Saavedra Fajardo's Idea de un príncipe político cristiano (Monaco, 1640) also depicts the olive tree in connection to the concept of peace [fig. 6]. Emblem 75, "In fulcrum pacis» (upon the fulcrum of peace), depicts a spear on the ground that serves as support to a vine and an olive tree that grow leaning on it. The pictura means that the prince obtains more glory through keeping peace and abundance (represented by both plants) than through the arms (represented by the spear). In the light of this symbolic visual tradition, Bocángel's reference to the olive crown can be read as an indirect reference to Olivares's "war-mongering» as opposed to the Admiral's bringing of peace after the battle, and as a warning that leaders need more than arms to be conquerors.

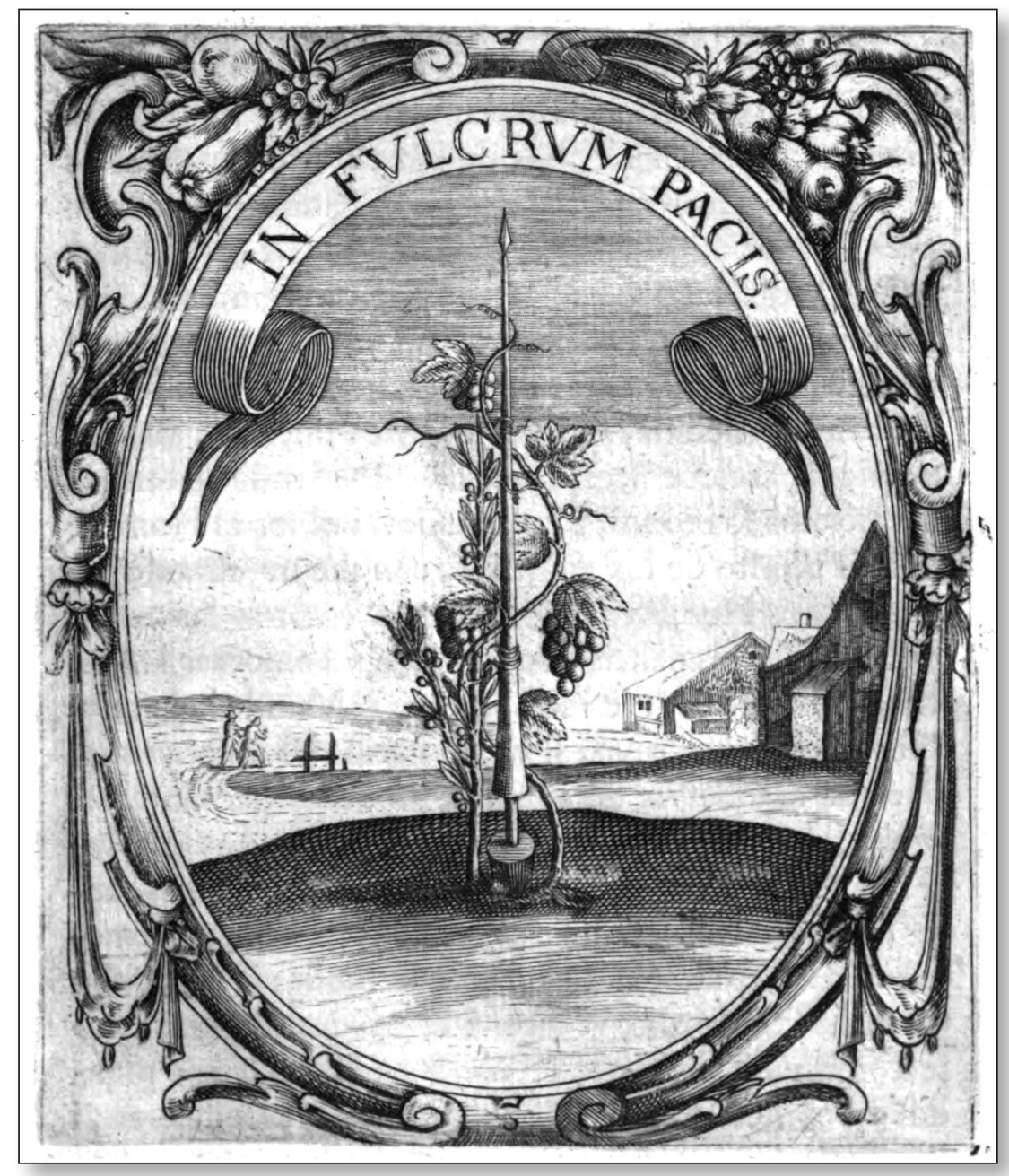

Fig. 6. Diego Saavedra Fajardo, Idea de un Principe Politico Christiano (Monaco, 1640). Emb. 75 (Image courtesy of Bayerische Staatsbibliothek München, shelfmark Res/4 Pol. g. 185, folio 544, URN urn:nbn:de:bvb:12-bsb10909476-6). 
Dadson argues that the first three verses are a reference to the Count-Duke, the Admiral's adversary (Dadson, 1983: 44-3), the word "olivas" (3) being a play-on-words with the last name "Olivares»; thus, the depiction of the Admiral's brow as "dos veces impedida / de olivas $y$ laureles vencedores" (2-3) would point at the valido's negative policies towards the Admiral as constraints or obstacles (Dadson, 2000: 637, n. to verses 2-3). ${ }^{10}$ While this is a possible reading, the consideration of the various visual symbolic meanings of the olive tree can shed a new light on the objectives and significance of the silva, as well as on the role of the poet at the Spanish Baroque court. Both the laurel and the olive can be read as a reference to the Admiral's achievements in war and peace- as both perfect soldier and model citizen- because the olive, like the laurel, often symbolized triumph and victory in tradition:

[t]he [...] significance of the olive as a token of good fortune may be seen in its use as a prize in various athletic contests. In the Olympic games, for instance, the victors were crowned with branches of wild olive, and tradition had it that they originally slept on them. (Luyster, 1965: 150)

Moreover, the laurel could also symbolize armistice, as classical sources such as Pliny's Natural History confirm: "The laurel itself is a bringer of peace, inasmuch as to hold out a branch of it between enemy armies is a token of a cessation of hostilities» (15.40.133). Thus, the layers of meaning multiply: if the laurel and the olive can be applied to war as well as to peace, the adjective "vencedores" (3) refers to both crowns. This reading complicates the interpretation of the stanza as a reference to the "obstacles» caused by the Count-Duke. ${ }^{11}$ It is, therefore, possible to interpret their presence as a reaffirmation of the leader's military skill and of his capacity to end war, which would position him morally above Olivares and his military ambitions. The idea of an olive crown as an impediment loses strength in view of its multiple connotations in visual tradition.

These ambiguities are resolved in the reading of the verses that follow. After painting the Admiral's portrait, the poetic voice exhorts him to lay aside the arms- a metonymy for war and his duties-, and listen to a "portrait» of Juan de Cetina's bride, making room for the enjoyment of the lover's sighing ( "dulce ventilar del aura pura, /... de suspiros... atentos / que dedica un garzón a una hermosura», 7 and 9-10). The implication is that the prince ought to be able to dedicate some «leisure» time to intellectual endeavors. In this context, it makes sense to interpret the two crowns that adorn the leader's brow not as impediments to his career that spring from the schemes of an adversary, but as obstacles to the enjoyment of poetry, and by extension, the acquisition of learning, a necessary tool for good government. This new reading implies the framing of the silva in the broader context of the debate of «las armas y las letras", central to early modern Spanish culture.

Bocángel's recourse to botanical imagery supports the argument for the silva as a defense of letters because it connects the Admiral to the concept of the literary patron. On the one hand, the laurel did not only symbolize war and peace, but it had deeply rooted symbolic connections to poetry and letters (Beard, 2007: 50, Trapp, 1958: 227). Works like Ripa's Iconologia depict "Poesia" as a female figure who "Si corona di lauro, il quale sta sempre verde, $\theta$ non tome forza di fulmine celeste, perche la poesia fa gl'huomini immortali, e gli assicura da colpi del

10. "Impedir» means "embarazar, poner obstáculos», that is, to lay obstacles before something (Diccionario de Autoridades, s.v. «Impedir», <http://web.frl.es/DA.html.> 01-17-18).

11. Spanish will typically make an adjective like "vencedor» masculine plural to describe two nouns joined by the conjunction "y" [and] when the noun positioned first is feminine and the noun positioned last is masculine. It is possible, then, that "vencedores" also modifies "olivas". In fact, all the botanical images in the silva can symbolize triumph, including ivy, which appears in the last stanza. 
tempo, il quale fuol tutte le cose ridurre all'oblivione» (1613: 156, II). Similarly, "furore poetico», the Platonic idea the divine fury behind any act of poetic creation, is portrayed as a young man adorned by both laurel and ivy: "Giovane vivace, \& rubicondo con l'ali alla testa, coronato di lauro, \& cinto di d'edera, stando in atto di scrivere: ma con la faccia rivolta verso il Cielo" (1613: 257-59). The laurel could also signify the maximum poetic achievements, hence the crowning with laurel of poets such as Dante, Petrarch, and Vergil. This tradition is the origin of the title poeta laureatus, which celebrates and recognizes a poet's "creative act of prophetic and poetic production" (Heckscher, 1992: 210).

The early modern Spanish emblem book renders this tradition visually in works like Hernando de Soto's (1568- ?) Emblemas moralizadas (Madrid, 1599). Soto's emblem 14, "Virtus laudata crescit / Praemiata florescit» (Virtue praised increases, / it flourishes when rewarded) [fig. 7], depicts one of the highest poets, Vergil, as a man crowned with laurel who holds a book in his hand in reference to virtue, which grows when it is praised, as happened with the Roman poet, who was honored and praised by his Emperor. ${ }^{12}$ Emblem 9 relates the laurel tree to the idea of multiplication, but in a negative sense: the pictura refers to the abundance of bad poets at the time through a reference to the myth of Apollo and Daphne, whom Gaia transformed into a laurel tree to save her from Apollo's pursuits, with the image of several laurel trees. These emblematic representations highlight the idea of the growth or increase of virtue; similarly to the greatest poets, the perfect leader is also adorned by the highest virtues, such as extreme valor and righteousness, and he ought to be praised and honored for them. Nevertheless, the parallelism implied between the figure of the political leader and that of the highest poet reinforces the idea of the prince as a man of intellect, and not merely a soldier.

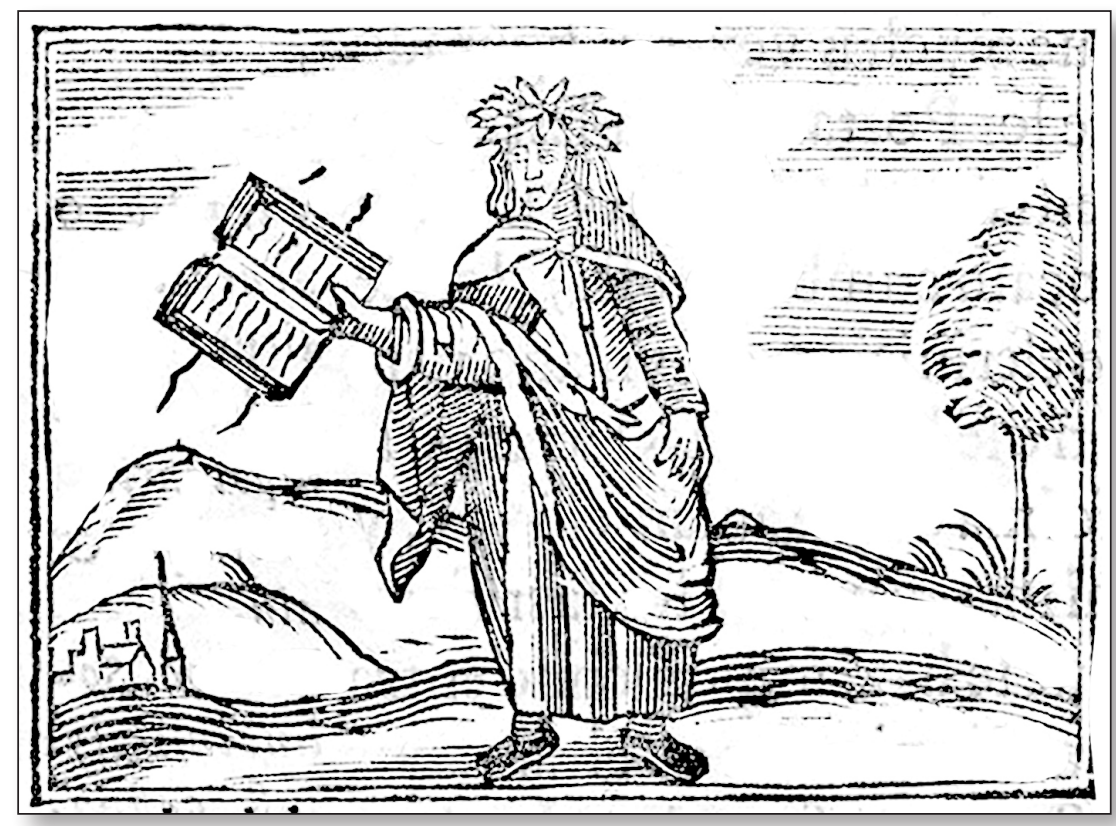

Fig. 7. Hernando de Soto, Emblemas Moralizadas (Madrid, 1599). Emb. 14 (Image courtesy of Biblioteca Virtual del Patrimonio Bibliográfico, Ministerio de Cultura, Educación y Deporte de España).

12. <http://www.bidiso.es/EmblematicaHispanica/> 2-01-18.

IMAGO, NÚM. II, 2019, I I |-133 
As the tree presented to the city of Athens by Pallas Minerva, the olive tree also had strong symbolic connections to learning, wisdom, and intellectual endeavor in general. Together with the laurel, its presence in the verbal portrait of the Admiral implies the necessity of the leader to the recourse to letters as well as to arms, a central idea in the tradition of the speculum principum. In Príncipe perfecto (Léon, France, 1662), the Spanish Jesuit Andrés Mendo (1608-1684) conveys this message in emblem 18, "Armis et litteris" (by arms and letters) [fig. 8]. The pictura depicts goddess Pallas Athena dressed in armor, accompanied by an owl, and holding a shield with the head of the Gorgon and a spear, as well as a book and a branch of olive. The emblem means that both arms and science or knowledge can give counsel to the prince, since he cannot rule without the sciences nor defend his people without the use of arms. ${ }^{13}$ The presence of the olive underscores the opposition MinervaMars because it symbolizes of the necessity of peace but also of learning and wisdom in good government.

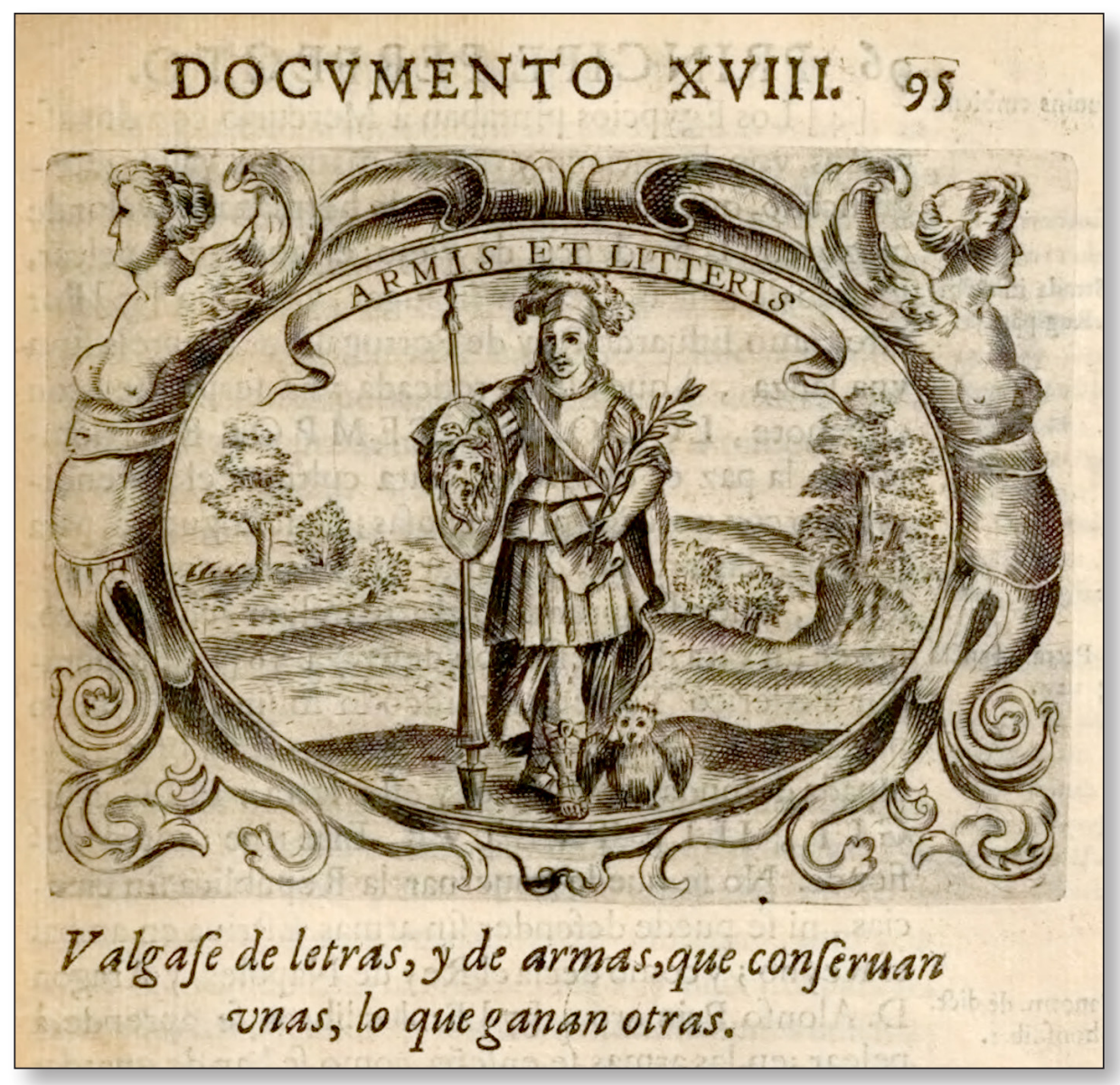

Fig. 8. Andrés Mendo, Príncipe Perfecto (Léon, 1662). Emb. 18 (Image courtesy of Bayerische Staatsbibliothek München, shelfmark Passau, Staatliche Bibliothek - S nv/Yge 242, folio 95r, URN urn:nbn:de:bvb:12-bsb11347923-2).

13. Ib. 
Another speculum principum, Diego Saavedra Fajardo's Idea de un príncipe politico christiano (Monaco, 1640), conveys a similar warning regarding the education of the prince. Emblem 4, "Non solum armis» (not by weapons alone) [fig. 9], depicts a royal crown placed on top of two books, one by Euclid, representing sciences, and one by Homer, representing letters; a plume of feathers is depicted in the center of the crown to symbolize their "ornato, conservación, $y$ defensa». Recurring to the authority of Justinian, Saavedra Fajardo explains that the prince must use the law as well as the force of arms to reign. But the author also elaborates on the idea of the necessity of letters in the sense of knowledge and learning. Because the prince is always occupied in his affairs, it is enough that he rewards "los ingenios para que en sus Reinos florezcan las sciencias [porque] los ingenios más científicos [...] pueden enseñar al Príncipe las artes de reinar, juntamente con las sciencias". On the authority of Spanish King don Alonso, he states that the arts are necessary for the prince - «es precisamente necesario en el Príncipe el ornamento i la luz de las artes»-, especially because the leader who does not cultivate knowledge will have to depend on the wisdom of others, thus becoming a servant to them.

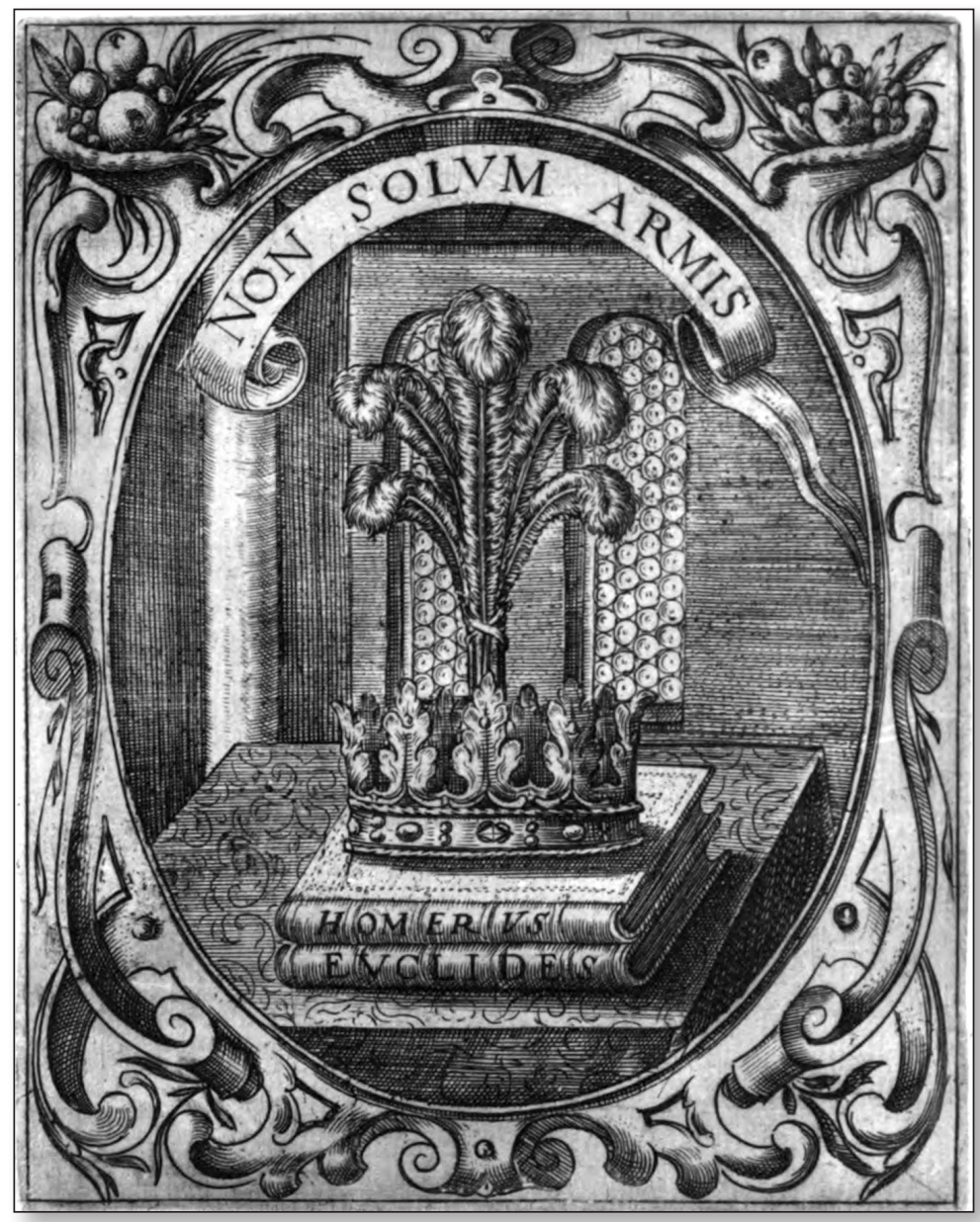

Fig. 9. Diego Saavedra Fajardo, Idea de un Príncipe Político Christiano (Monaco, 1640). Emb. 4 (Image courtesy of Bayerische Staatsbibliothek München, shelfmark shelfmark Res/4 Pol. g. 185, folio 24r, URN urn:nbn:de:bvb:12-bsbl0909476-6). 
According to Saavedra Fajardo, it is enough for the prince to have a broad familiarity with letters and sciences, and so those inferior to him can be allowed to surpass the prince in knowledge. Consequently, the prince can reserve the acquisition of learning in both the arts and the sciences for his leisure time: "Conténtese con ocupar el ocio con tan noble exercicio". The key role of arts and letters is the instruction of the prince in the line of the docere et delectare. In terms of life at court, Saavedra Fajardo recommends that «en los divertimientos, i juegos pueriles, vaya tan disfrazada la enseñanza que la beva el Pe [Príncipe] sin sentir" (1640: 30) (in their entertainments, and childlike games, may truth be disguised so that the Prince drink it without realizing). In this context, a poetical text like Bocángel's silva is also a "divertimiento" in itself that can fill the Admiral's time when he rests from his duties, but also an educational tool, if read correctly. Thus, the silva can be read as a metapoetic text in defense of poetry and as a speculum principum on the virtues that ought to adorn the perfect leader and on the role of letters at court.

The last stanza seals Bocángel's defense of letters by means a third and last botanical image: the ivy. From verse 154, the poetic voice attracts the reader's attention from doña Jerónima's «portrait» back to the Admiral. The poetic voice depicts the Admiral as a strong, firm column -reminiscent of statues of Roman generals-, and asks him to allow a climbing ivy to attach itself to him, and thus to grow in his protection:

De Dafne, pues, la fugitiva planta

(gran Enríquez) que sube altivamente a ceñir vuestra frente,

dé lugar a esta hiedra que se planta

a su pie generoso,

y entretejida al tronco vigoroso,

no ya del sol, del tiempo fugitiva,

dure, medre, fructúe, crezca, viva. (165-70, emphasis added $)^{14}$

Dadson notes that the ivy was traditionally related to love and lust -indeed, Ripa relates the ivy to "carezze amatorie» (1613: 132)-, and therefore reads these final verses as a reference to the married couple who seeks the Admiral's protection. The ivy had different symbolic meanings in visual and literary tradition of early modern Europe, which drew mainly from classical sources.

However, the crown of ivy was also the symbol of the immortality of poetry. For Trapp, «ivy and bay [...] had strong poetic connotations in the ancient world" as «the plants of Phoebus and Bacchus» (1958: 227); Wittkower points out that «For Plato and the Platonists ivy is the symbol of Furor Poeticus, i.e. of the divine form of frenzy» (1939: 202). In Ripa's account, ivy is indeed the plant chosen to adorn the poets's brow: "Di Hedera, $\theta$ Alloro si coronavano indifferentemente tutti li poeti. Horatio poeta Lirico, si gloriava del'hedera" (1613: 4-5). The emblematic tradition reflects these conceptions by connecting the ivy to the concept of study and the immortal works of poets. In emblem 205 of Alciato's Emblemata (Padua, 1621) [fig. 10], "Hedera» (the ivy), the pictura represents the ivy along with the harp of Apollo and a scroll of parchment. Probably drawing from book 16 of Pliny's Natural History, the emblem relates the ivy to the crowns with which poets adorned themselves, specifying

14. «Thus, let Daphne's fugitive plant / (great Enríquez) that haughtily climbs / to embrace your brow / give room to this ivy that is planted / at your generous foot / and intertwined to the vigorous trunk, / not from the sun, but from time fleeing, / may it last, prosper, fructify, grow, live». (The translation is mine) 
that «Poets are pale (like the yellow of the plant) because of their continuous study, but their fame and glory is evergreen like the plant itself». The Paris 1584 edition of the book explains that poets find consolation in the idea of the praise of their work: "ainsi sont ils consolez / d'esperance, $\theta$ soulagent les chagrins $\theta$ dif- / ficultez de leurs estudes par l'opinion qu'ils / ont d'une louange immortelle»..$^{15}$ The ivy is inseparable from the concept of eternal fame and persistence of poetic works in memory, which has implications regarding the silva's relative importance in Baroque court poetry.

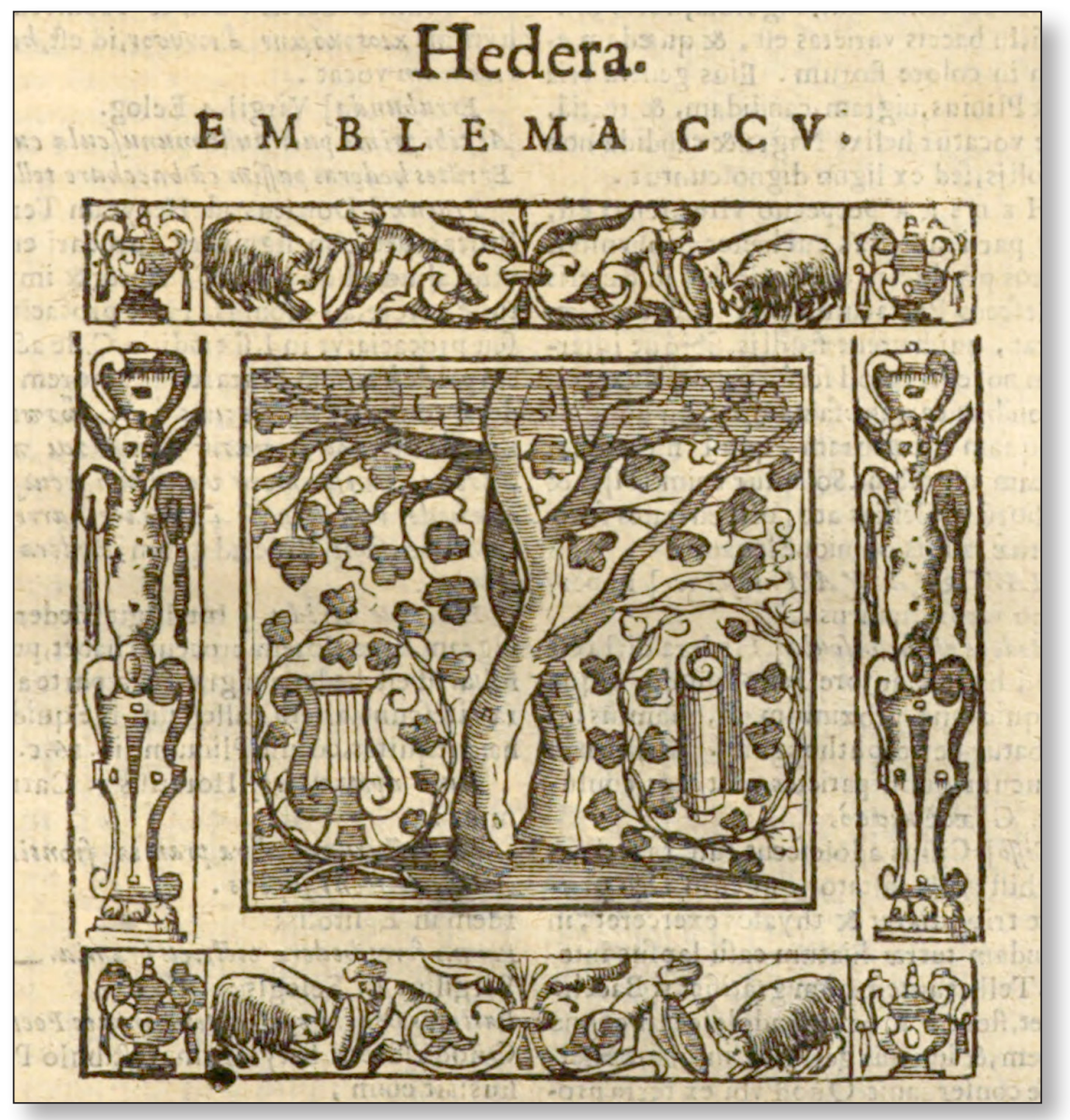

Fig. 10. Andrea Alciato, Emblemata (Padua, 1621). Emb. 205 (Image courtesy of Bayerische Staatsbibliothek München, shelfmark Regensburg, Staatliche Bibliothek - 999/4Lat. rec.40, folio 865r, URN urn:nbn:de:bvb:12-bsb11068683-2).

The poetic origin of tradition of the ivy that creeps up a laurel of victory has been identified as Vergil's eclogue 8 (Trapp, 1958: 233): «Accept these songs that I began at your command. / Let ivy ring your brows now bound in victory laurels» (12- 13). Bocángel's adaptation of these verses responds to what Stephen Greenblatt has called «self-fashioning»:

15. <emblems.arts.gla.ac.uk/alciato/emblem.php?id=FALc204> 2-12-17.

IMAGO, NÚM. I I, 2019, I I I- I33 
presenting himself as a new Vergil, the poet intercedes for both his works and for the role of poetry at court though a double praise of the leader as imperator inuictus deserving of the ivy crown of the patron or critic (Trapp, 1958: 229). The dedication of the crown of ivy to the Admiral implies a search for the protection of poetry in the Spanish court. The perfect leader is the one who allows the ivy of poetry to grow, because letters are useful sources of the knowledge that is needed to rule, as the emblematic tradition reflects. However, the silva introduces a subtle deviation from Vergil. The poetic voice does not suggest that ivy will be joined with the laurel, but that the latter will rather leave room for the ivy on the Admiral's brow, perhaps allowing it to grow in its stead and thus escaping the passage of time: "De Dafne, pues, la fugitiva planta / [...] dé lugar a esta hiedra [...]" (163 and 166, emphasis added). ${ }^{16}$ This implies the idea of the eternity of poetical works.

The visual symbolic tradition suggests new nuances of meaning and new possible objectives of the silva as a whole. ${ }^{17}$ However, the text still poses yet one final question: there seems to be a textual disconnection between the opening and closing of the poem and its apparent main task, the verbal portrait of doña Jerónima. In this description, both the nature of the metaphors and the general tone the poetic voice employs seem somewhat out of place in a nuptial poem, which consequently makes the text appear as obscure, ambiguous, and even «ironic» (Dadson, 2000: 639, n. to vv. 64-73).

The verbal portrait of the bride starts between verses 30-126, where the reader finds the poetic voice undertaking, and mostly failing at, the task of "painting" the physical beauty of Jerónima. Drawing from the tradition of ut pictura poesis, the topos of ineffability is present in the poetic voice's mocking of its own incapacity to render her perfections accurately and deservingly in words. For instance, in verses 34-5, the poetic voice shames its own daring in undertaking such a task with a "clumsy hand» (44-7) because it will probably result in a failed attempt at organizing chaos: "por ser manos todo, está sin manos» (27). This verse seems to play with the meaning that "mano» typically has in painting: «En la Pintura y en la Albañilería es la capa de barniz o de hyeso que se da al quadro, o a la pared" (Autoridades), a sense of incompleteness. The failed attempt at «painting» the portrait of the bride has its root in the poetic voice's ironically self-declared lack of artistic skill, the reason why it cannot give the poem the appropriate coating of verbal varnish. ${ }^{18}$

The topos of verbal portraiture as a daring act runs like a thread through these verses, reinforced by the reference to myths of failure and fall, such as Tantalus (85) and, as Dadson suggests, Icarus (159-162). The description of the woman's body beings in verse 52; following the convention of the descriptio puellae of Petrarchan poetry of painting the lady in words from head to foot, like a statue of Venus, the poem traces a descending movement that contrasts with the climbing ivy's ascent in the last stanza. In its exposition of Jerónima's unparalleled beauty, the poetic voice recurs to hyperbole and to the choice of

16. According to the Diccionario de Autoridades, «lugar» means «tiempo, espacio, oportunidad u ocasión», as well as «empleo, dignidad, o puesto elevado». These verses seem to imply a petition for a new place of poetry and letters. (<http://web.frl.es/DA.html.> s.v. «lugar», 01-17-18).

17. Moreover, the case of the supposed enmity between Olivares and Bocángel in which Dadson bases his argument remains a hypothesis. The critic notes Bocángel's praising of Olivares a year before in "Lauro cívico", and ventures the conclusion that «If there were any underlying antagonism between Olivares and Bocángel, it must have derived from some personal cause rather than from any political motive» (1979: 39). Dadson states the same ideas in 1983: 45 .

18. The word "mano" had multiple other meanings that reinforce the connotations of failed skills: «la persona hábil y diestra en lo que executa con las manos", or "dominio, imperio, señorío y mando que se tiene sobre alguna cosa" (Diccionario de Autoridades, s.v. "Mano», <http://web.frl.es/DA.html.> 01-17-18). 
rather unexpected conceits to imply that traditional descriptions would do her beauty no favor. ${ }^{19}$

On the other hand, the poem challenges the topical metaphors and similes of the genre, employing conceits that strike because of their uniqueness. In verses 52-63, Jerónima's hair is not compared to gold, like in Renaissance descriptions of female beauty such as Garcilaso de la Vega's (1498-1536) sonnet 23, but to the honey produced by a busy bee. Interrupted in the act of gathering pollen from a flower, the bee leaves a track of "half-woven juice» (59), ultimately turned into precious "gold» by the heat of the sun. ${ }^{20}$ The woman's eyes are like deep blue mirrors that cause Cupid's jealousy (74-81); her forehead is so beautiful that it cannot be compared to anything as lowly as a simple flower that grows in the soil (64-73). The list of similes and metaphors continues, building on the rhetoric of hyperbole. These twists on the conventional imagery and conventions of the descriptio puelle contribute to making their relationship to the dedicatory stanzas seem even more obscure, because they contrast with the laudatory portrait of the Admiral. The descriptions of the bride seem to contain an underlying irony, and have been read as too "estilizadas y estereotipadas" (Dadson, 2000: 639, n. to verses 64-73). ${ }^{21}$

However, Bocángel's motivation on seemingly mocking literary conventions is far from obscure when considered in the light of the symbolic visual tradition. Just as the dedicatory stanzas purposely fashion the male other as a model figure, the verbal portrait of the bride shapes the female as virtuous - and therefore adequate for protection of the Admiral's house along with her husband. Most importantly, it responds to a conscious self-fashioning on behalf of the poet. If in early modern Europe human beings are «the ideological product of the relations of power in a particular society" (Greenblatt, 1980: 256), then Bocángel's self-presentation as a poet in search for patronage requires "showing off» his literary skills, which prove him capable of toying with poetical tradition and subverting it at will. In its last stanza, the poem fulfills its initial promise to alleviate and entertain the tired soldier by means of art; a leader who can enjoy his poetic genius will probably make room for art in his household. More than a playful verbal exercise, the poem becomes a latently powerful cultural artifact that encodes a message for a society that was "habituada a la lectura de los símbolos, y que pone la agudeza entre las virtudes fundamentales del caballero cortesano» (Gállego, 1991: 13). Bocángel's display of agudeza (wit) and poetic skill aims at the framing of poetry as a necessary element in life at court; las letras must complement las armas because a leader needs knowledge to rule, and also because immortal poetry can sing the everlasting fame of the prince who acts correctly. ${ }^{22}$

19. Bocángel's use of color subverts its tradition in which red refers to woman's rosy cheeks in contrast to the "nieve y plata" of her cold disdain (and skin, representing chastity). In the silva, red or purple show on the poetic voice's face when he ironically blushes at his own poetical daring.

20. "Quilatar" or "aquilatar" means "Subir de estimación y precio, reduciendo a mayor perfección, y de mayores quilates el oro, plata, y otros metales preciosos» (Diccionario de Autoridades, s.v. «Quilatar», <http://web.frl.es/DA.html.> 01-1718).

21. Dadson reads Bocángel's imagery as purposefully commonplace and, therefore, ironic: "Es difícil imaginarse a un Bocángel escribiendo estos versos sin darse cuenta de lo trillados que resultan" (2000: 639, n. to vv. 64-73). Further research is needed on the silva in the context of visual culture, especially because this type of celebratory poem could accompany a portrait in festivities. In early modern "libros de fiestas" epkphrasis was used to "ponderar los personajes, lugares y circunstancias que rodean el acontecimiento" (García Bernal, 2018: 3). On festivities in early modern Spain, see López Poza, 1999.

22. This might imply a critique of Olivares, who does not take this into account. This reading clashes with Blanco's perception of Bocángel as little interested in politics, «la version la plus immaculée du conformisme» (1988: 203).

IMAGO, NÚM. I I, 2019, I | | - | 33 
The multiple textual references that Dadson identifies to myths of failure or fall become relevant as potential warnings on political tactics. Moreover, they complement other central tensions brought about by two classical references in the text: on the one hand, the myth of Apollo and Daphne, the obvious reference in the last stanza. The myth speaks of pursuit and violent conflict triggered by passion, running parallel to the military endeavors of the Admiral, inspired by love of la patria. On the other hand, the story of the Trojan horse (26) (Virgil's Aeneid, book II (30-19 B.C.,) adds a connotation of deceit that might seem out of place in a nuptial poem (Dadson, 2000: 643, n. to verse 163). Nevertheless, as a poetic image that speaks of the potentiality of a hidden threat, the presence of the horse is possibly a reference to Olivares's intentions and presence at court.

The image of Trojan horse is central to the understanding of the silva because the text itself is not what it seems: in its interweaving connotations of love and pursuit, aspiration and protection, conflict and peace, the silva is a true "selva" (forest, jungle) of playful, ambiguous tone. ${ }^{23}$ The conjunction of poetic and visual image generates textual tensions that open up different possibilities of interpretation. The silva addresses the very issue of poetry, questioning its role, especially in relation to power. It also reshapes the poem into a mirror of cultural tensions and perceptions of power: the power of words to serve a leader (fashioning, supporting, or destroying him), the power of leaders over their subordinates (especially in matters such as marriage and social status), and the power of poetry to mediate between them.

Pursuit, violence, and desire, central connotations in the story of Apollo's persecution of Daphne, become key to poetic language itself when it struggles to depict the other, particularly in the case of the subordinate other. The poetic text must describe the beautiful female betrothed to power as an assurance of stability, while facing its own instability in presenting her case. It must also elaborate a panegyric of those in power, fashioning them as lenient benefactors, while presenting itself as an aiding tool to them. More importantly, it must warn them of the dangers of bad government, while reassuring the powerful of their righteous condition as perfect princes. As an echo of Mendo's emblem, the text seems to suggest that the need for a strong military leader might incline a monarch to the wrong favorite- as, in order to retain what has been gained by the force of arms, both the leader and the people should cultivate knowledge. In this sense, the Baroque poet finds itself having to perform adequately not only as a work of art, but also as contender in the national political arena.

The poem also functions as a commentary on the role of the female in struggles of power. Like the bride herself, the silva becomes an object: it provides the powerful with a verbal portrait of a woman to be «looked at» and given or denied approval, to be consumed or discarded by the powerful. The playful, self-deprecatory attempts of the poetic voice to present the bride to the Admiral's household are an exercise in ironic self-deprecation; like doña Jerónima, poetic language itself is aware of its need for protection at court. To obtain it, it must reshape itself into a sweet, pleasant air that appeases the warrior, a beautiful object that merits his attention. At the same time, it must also fashion the other who is to bestow such protection. In this sense, the celebratory poem becomes also an argumentative one, a piece of oratory that presents and defends its own case. The poetic voice's use of

23. A study of the Trojan horse in early modern visual culture remains open to future research; several Spanish books of emblems use it in reference to religious dogma and war, as Soto's Emblemas moralizadas (Madrid, 1599 , embl. 5), Saavedra Fajardo's Idea de un príncipe político christiano (Monaco, 1640, emb. 25), and Sebastián de Covarrubias's Emblemas morales (Madrid, 1610, emb. 52, cent. I) 
unexpected imagery and tone shakes the reader into questioning poetic language itself, the validity of the standards of female beauty, and the role of women and men who serve the powerful.

Bocángel's silva is a space where the conjunction of word and image blurs the boundaries of laudatory poetry and poetic portraiture, which function as political tools by crossing over to the realm of the speculum principum. Like the ivy, the poem grows in the shade of the tradition of laudatory poetry and the poetical portrait, but latches itself to other literary traditions. Far from being a rigid compartment, the occasion poem becomes a dialogic space in which the poetic voice addresses specific cultural issues.

Moreover, the previously analyzed interactions of word and image and the textual tensions they interweave make it difficult to sustain the argument that the role of a court poet in Baroque Spain is a passive one. As a language artisan, the poet is aware of the necessity to shape the text as a stage where cultural and sociopolitical tensions can be performed, a locus where it is possible to engage in discourses of appearance and truth, power and patronage. As a cultural artifact, the early modern silva can encode underlying tensions, whether literary, political, or sexual; in the light of the emblem, Bocángel's silva nupcial is no mere poetical toy: a textual Trojan horse that hides two weapons in its belly, a mirror of princes and a defense of poetry.

\section{WORKS CITED}

Alciato, A., And López, D. [1615]. Declaración Magistral sobre las Emblemas de Andrés Alciato con Todas las Historias, Antigüedades, Moralidad, y Doctrina Tocante a las Buenas Costumbres. Nájera, Juan de Mongaston.

Alciato, A., Mignault, C., Sánchez de las Brozas, F., Morelli, F., Thuilius, I., and Pignoria, L. [1621]. Andreae Alciati Emblemata: cum commentariis Claudii Minois i.c. Francisci Sanctii Brocensis, $\theta$ notis Laurentii Pignorii Patavini: novissima hac editione in continuam unius Commentarij seriem congestis, in certas quasdam quasi classes dispositis, $\theta$ plusquam dimidia parte auctis, opera et vigiliis Ioannis Thuilii Mariaemontani Tirol....: opus copiosa sententiarum, apophthegmatum adagiorum, fabularum, mythologiarum, hieroglyphicorum, nummorum, picturarum $\theta$ linguarum varietate instructum $\theta$ exornatum : proinde omnibus antiquitatis $\theta$ bonarum literarum studiosis cùm primis utile: accesserunt in fine Federici Morelli ... corollaria $\theta$ monita, ad eadem Emblemata. Padua, Tozzi.

ALCIATO AT GLASGOW <https://WwW.emblems.arts.gla.ac.uk/alciato/>, 2-12-17.

Alda Tesán, J.M. [1947]. "Bocángel y su Obra Poética», Boletín de la Biblioteca de Menéndez Pelayo, 23, 5-28.

Auliard, C. [2001]. Victoires et Triomphes à Rome. Droit et Réalités sous la République. Paris, Presses Universitaires Franc-Comtoises.

BarinI, C. [1952]. Triumphalia: Imprese ed Onori Militari durante L'Impero Romano, Turin, Società Editrice Internazionale.

Bastien, J.L. [2007]. Le Triomphe Romain et son Utilisation Politique à Rome aux Trois Derniers Siècles de la République, Rome, École française de Rome.

Beard, M. [2007]. The Roman Triumph, Cambridge [MA], Belknap Press of Harvard University Press. 
Benítez Claros, R. [1950]. Vida y poesía de Bocángel, Madrid, Consejo Superior de Investigaciones Científicas.

Bernat Vistarini A. \& Cull, J.T. [1999]. Enciclopedia de Emblemas Españoles Ilustrados, Madrid, Akal.

Biblioteca Digital de CASTILla y León <https://bibliotecadigital.jcyl.es> 2-01-18.

Biblioteca Digital de Emblemática Hispánica

<https://www.bidiso.es/EmblematicaHispanica/> 2-01-18.

Blanco, Ms. [1988]. "La Poèsie Monumentale de Gabriel Bocángel», in Jean-Claude Chevalier and Marie-France Delport (eds.), Mélanges Offerts a Maurice Molho, vol. I, Paris, Editions Hispaniques, 203-22.

BorJa, J. [1581]. Empresas Morales a la S. C. R. M. del Rey don Phelipe, Nuestro Señor, Dirigidas por don Ivan de Borja, de su Consejo y su Embaxador Cercala M. Cesarea del Emperador Rudolpho II, Prague, Iorge Nigrin.

BRIghtwell, P. [1979]. "The Spanish Origins of the Thirty Years' War», European Studies Review, 9, 4, 409-31.

Brilliant, R. [1999]. "'Let the Trumpets Roar!' The Roman Triumph», in B. Bergmann and C. Kondoleon (eds.), The Art of Ancient Spectacle. CASVA Studies in the History of Art, Symposium Papers 34, Washington, New Haven, Yale University Press, 221-229.

Camerarius, I. the Younger [1661]. Symbolorum et Emblematum ex Re Herbaria. Frankfurt, Impensis Iohannis Ammonij.

CANO, J.L. [1952]. «Revisión de Bocángel», Cuadernos Hispanoamericanos, 26, 316-18.

Carreira, A. [2016]. "El Conde-Duque de Olivares y los Poetas de su Tiempo», Nueva Revista de Filología Hispánica 64, 2, 429-456.

Cooper, J.P., ED. [1970]. The Decline of Spain and the Thirty Years' War, 1609-48/49. Cambridge [England], Cambridge University Press.

Cossío, J.M. DE. [1952]. "El 'Hero y Leandro' de Bocángel», in J. M. Cossío (ed.), Fábulas Mitológicas en España, Madrid, Espasa-Calpe, 568-76.

Covarrubias y Horozco, S. [1610]. Emblemas Morales, Madrid, Luis Sánchez.

Dadson, T.J. [1976]. "An Autograph Copy of Gabriel Bocángel's El Cortesano Español», Bulletin of Hispanic Studies, 53, 301-14.

Dadson, T.J. [1976b]. "Poesías Inéditas de Bocángel: Poesías Nupciales», Boletín de la Biblioteca de Menéndez Pelayo, 52, 155-74.

Dadson, T.J. [1979]. "Political Comment in the Work of Seventeenth-Century Poet Gabriel Bocángel», in P. S. N. Russell-Gebbett, Nicholas Grenville Round, and Arthur Terry (eds.), Belfast Spanish and Portuguese Papers, Belfast, Queen's University of Belfast, 33-49.

Dadson, T.J. [1982]. "Some Problems Connected with the Printing and Dating of Gabriel Bocángel's La Lira de Las Musas», The Modern Language Review, 77, 4, 848-859.

Dadson, T.J. [1983]. The Genoese in Spain. Gabriel Bocángel y Unzueta, a Biography, London, Tamesis.

DaDson, T.J. [1983b]. «Guía Bibliográfica y Crítica de y sobre las Obras de Gabriel Bocángel y Unzueta», in Censo de Escritores al Servicio de los Austrias y Otros Estudios Bibliográficos, Madrid, Instituto "Miguel de Cervantes".

Dadson, T.J. [1984]. "Gabriel Bocángel's Consejos Cristianos, Morales, y Políticos: A New, Longer, and Better Text», Bulletin of Hispanic Studies, 61, 2, 151-164.

Dadson, T.J. (ed.) [1985]. La Lira de las Musas, Madrid, Cátedra.

Dadson, T.J. [1986]. «Nueve Cartas Autógrafas e Inéditas del Poeta Gabriel Bocángel y Unzueta», Boletín de la Real Academia Española 66, 266-298. 
Dadson, T.J. [1987]. «El Amor en la Poesía de Bocángel: Análisis de Algunos de los Sonetos de Filis", Edad de Oro, 6, 51-65.

Dadson, T.J. [1988]. «Una Comedia Problemática: El Emperador Fingido de Gabriel Bocángel», Criticón, 42, 53-64.

Dadson, T.J. (ed.) [1991]. La Casa Bocangelina: Una Familia Hispano-Genovesa en la España del Siglo de Oro, Pamplona, Ediciones Universidad de Navarra.

Dadson, T.J. [1992]. «La Psicología del Amor en los Sonetos a Filis de Bocángel», in Antonio Vilanova and Josep M. Bricall, and Elías Rivers (eds.), Actas del X Congreso de la Asociación de Hispanistas, I-IV, Barcelona, Promociones y Publicaciones Universitarias, 863-75.

Dadson, T.J. (ed.) [2000]. Obras completas de Gabriel Bocángel y Unzueta, Pamplona, Iberoamericana, Vervuert.

Dadson, T.J. [2002]. "A Golden-Age Poet and his Sources: Gabriel Bocángel Unzueta», in Stephen Boyd and Jo Richardson (eds.), Spanish Poetry of the Golden Age. Papers of a Colloquium held at University College Cork, Manchester, Dept. of Spanish \& Portuguese Studies, University of Manchester, 21-39.

DicCIONARIO DE AUTORIDADES <http://web.frl.es/DA.html.> 01-17-18.

Elliott, J.H. [1986]. The Count-Duke of Olivares: The Statesman in an Age of Decline. New Haven [CT], Yale University Press.

Fontana ElboJ, G. [1989]. "Algunas notas sobre la relación entre Boscán y Bocángel en sus poemas de Hero y Leandro", Cuadernos de Investigación Filológica 15, 1-2, 71 -85.

Gállego, J. [1991]. Visión y Símbolos en la Pintura Española del Siglo de Oro, Madrid, Cátedra.

GARCía Bernal, J.J. [2018]. «Triunfos del suceso: Cultura Festiva en las Postrimerías del Siglo de Oro", e-Spania, <http://journals.openedition.org/e-spania/27575>DOI: <http://10.4000/ e-spania.27575>. 12-10-19.

GonzÁLez, O. [2000]. "Artificio y Poder en la Pintura: la Visión Cortesana de Gabriel Bocángel», in Florencio Sevilla, Florencio and Carlos Alvar (eds.), Actas del XIII Congreso de la Asociación Internacional de Hispanistas: Tomo 1, Medieval, Siglos de Oro, Madrid, La Asociación, 565-570.

Greenblatt, S. [1980]. Renaissance Self-Fashioning: From More to Shakespeare, Chicago, University of Chicago Press.

Heckscher, W.S. [1992]. "Andrea Alciati's Laurel Tree and Its Symbolic Traditions», Emblematica 6, 2, 207-18.

Horace, and Moore C.H. [1902]. The Odes and Epodes, Volumes 1-3, New York, American Book Co.

Isidore, and Barney, Stephen A., Lewis, W. J., Beach, J. A. and Berghof, O. (eds. and transl.). [2006]. The Etymologies of Isidore of Seville, Cambridge; New York, Cambridge University Press.

La Rocca, E., and Tortorella, S. (eds.). [2008]. Trionfi Romani. Milan, Electa.

LESAFFER, R. [2006a]. "Defensive Warfare, Prevention and Hegemony. The Justifications for the Franco Spanish War of 1635 (Part I)», Journal of the History of International Law 8, 1, 91-123.

Lesaffer, R. [2006b]. "Defensive Warfare, Prevention and Hegemony: The Justifications for the Franco-Spanish War of 1635 (Part II)», Journal of the History of International Law 8, 1, 141-79.

López Poza, S. (ed.). [1999]. La Fiesta. Actas del Segundo Seminario de Relaciones de Sucesos, Ferrol, Sociedad de Cultura Valle Inclán. 
Luyster, R. [1965]. "Symbolic Elements in the Cult of Athena», History of Religions 5, 1, 133-63.

Mendo, A. [1662]. Príncipe Perfecto y Ministros Aiustados, Documentos Políticos y Morales. En Emblemas. Por el R. P. Andrés Mendo, de la Compañía de Iesús, Calificador del Consejo de la Inquisición Suprema, Lector de Teología, y de Sagrada Escritura en Salamanca, Añadido de las estampas en esta segunda Impressión, Léon, Boissat.

Mercado, L. [2016]. "Breaking the Myth: Bocángel's New Narcissus», Caliope, 21, 2, 19-36.

Mínguez Cornelles, V., and Rodríguez Moya, I. [2002]. "Olivares, retrato simbólico de una privanza", in Bernat Vistarini, A. and Cull, J. (eds.), Los días del Alción: Emblemas, Literatura y Arte del Siglo de Oro, Palma Mallorca, J.J. de Olañeta, 401-418.

Molho, M. [1987]. "El Soplo y la Letra: Gabriel Bocángel ante sus Escritos», Edad de Oro 6, 189-199.

Morros Mestres, B. [2001]. "Sentido y Fuentes de la Canción de Bocángel 'Al caso de Apeles' en La lira de las Musas», Dicenda: Cuadernos de Filología Hispánica, 19, 179-242.

Orozco Díaz, E. [1941]. "La muda Poesía y la Elocuente Pintura (Nota a unas Décimas de Bocángel)», Escorial, X, 282-290.

Ovid, and Miller, F.J. And Goold, G.P. (eds. and transl.) [1984]. Metamorphoses. Cambridge [MA], Harvard University Press; London, Heinemann.

Palafox y Mendoza, J. De. [1639]. Sitio y Socorro de Fuenterrabía y Sucesos del Año de 1638, Escritos de Orden y en Virtud de Decreto, Puesto Todo de la Real Mano de la Magestad del Señor Don Felipe $I V$, Madrid, Imprenta de Cat. del Barrio.

PARKer, G. [1984]. Spain and the War, the Thirty Years' War, London; Boston, Routledge \& Kegan Paul.

Payne, R. [1962]. The Roman Triumph, London; New York, Abelard-Schuman.

Peralta, M.E. [1961]. «En el Centenario de Góngora: Gabriel Bocángel y Unzueta», Universidad, L, 187-209.

Pliny the Elder and Rackham, H. (ed. and transl.) [1945]. Natural History, Cambridge [MA], Harvard University Press.

Ponce CÁrdenas, J. [2012]. «El 'Panegírico al Duque de Lerma.' Trascendencia de un Modelo Gongorino (1617-1705)", Mélanges de la Casa de Velázquez 42, 1, 71-93.

Popkin, Maggie L. [2016]. The Architecture of the Roman Triumph: Monuments, Memory, and Identity, New York, Cambridge University Press.

RIPA, C. [1613]. Iconologia, Siena, Appresso gli Heredi di Matteo Florimi.

SaAvedra Fajardo, D. [1640]. Idea de un Príncipe Político Christiano Representada en Cien Empresas, Monaco, Nicolao Enrico.

Sото, H. [1599]. Emblemas Moralizadas por Hernando de Soto, Contador y Veedor de la casa de Castilla de su Magestad, Madrid, Várez de Castro.

Sumi, G.S. [2005]. Ceremony and Power. Performing Politics in Rome between Republic and Empire, Ann Arbor [MI], University of Michigan Press.

Torres, I. [1998]. "Critics against Bocángel: Presenting a Case for the Defence», Bulletin of Hispanic Studies, 75, 173-190.

Torres, I. [2000]. "A Great Mythological Cop-Out? Hero and Leander on the Verge of Significance», Bulletin of Hispanic Studies, 77, 4, 305-28.

Torres, I. [2006]. «A Small Boat over an Open Sea? Gabriel Bocángel's 'Fabula de Leandro y Hero' and Epic Aspirations", The Polyphemus Complex. Rereading the Baroque Mythological Fable, Bulletin of Hispanic Studies Monographic 83, 2, 131-63. 
Trapp, J.B. [1958]. "The Owl's Ivy and the Poet's Bays. An Enquiry into Poetic Garlands», Journal of the Warburg and Courtauld Institutes 21, 3/4, 227-55.

VIRGIL AND KRISAK, L. (ed.) [2010]. Eclogues, Philadelphia, University of Pennsylvania Press.

Versnel, H.S. [1970]. Triumphus: An Inquiry into the Origin, Development and Meaning of the Roman Triumph, Leiden, Brill.

Wilson, P.H. [2009]. The Thirty Years' War: Europe's Tragedy. Cambridge [MA], The Belknap Press of Harvard University Press.

WittKover, R. [1939]. "Transformations of Minerva in Renaissance Imagery", Journal of the Warburg Institute, 2, 3, 194-205. 
